This is an Accepted Manuscript of an article published by Taylor \& Francis in the journal Local Environment on 19 Nov 2018, available online:

https://doi.org/10.1080/13549839.2018.1536698

\title{
Blocking Pipelines, Unsettling Environmental Justice: From Rights of Nature to Responsibility to Territory
}

\author{
Leah Temper ${ }^{1,2, *}$ \\ ${ }^{1}$ Department of Natural Resource Sciences, McGill University, Montreal, Quebec, \\ Canada \\ ${ }^{2}$ ICTA, Universitat Autònoma de Barcelona, Bellaterra, Spain \\ *leah.temper@gmail.com
}

\section{Part of the Special Issue on Environmental Justice \& Epistemic Violence}

\begin{abstract}
:
Indigenous peoples are among the most affected by environmental injustices globally, however environmental justice theory has not yet meaningfully addressed decolonization and the resistance of indigenous communities against extractivism in the settler-colonial context. This paper suggests that informing environmental justice through decolonial analysis and decolonizing practices can help transcend the Western ontological roots of environmental justice theories and inform a more radical and emancipatory environmental justice.
\end{abstract}

The Unist'ot'en Resistance and Action Camp blocking pipelines in northwestern British Colombia, Canada, their "Reimagined Free Prior and Informed Consent protocol" and the Delgamuukw case are described to discuss limitations of the state and legal framework for accommodating a decolonial and transformative environmental justice. A decolonial analysis informed by these two moments of Wet'sewet'ten history suggest limits and adaptations to the trivalent EJ framework based on recognition, participation and distribution. It is argued that a decolonizing and transformative approach to environmental justice must be based on self-governing authority, relational ontologies of nature and epistemic justice and the unsettling of power through the assertion of responsibility and care through direct action.

This discussion is placed in the context of the expansion of the concept of ecological rights, for example through the enshrining of the "Rights of Nature" in the constitutions of countries such as Bolivia and Ecuador, to highlight the inherent tensions in the translation of indigenous cosmo-visions into legal systems based on universalist values. 


\section{Introduction}

The Wet'suwet'en First Nation territory spans for over 22,000 km in NorthWest British Columbia, Canada, and lies directly in the path of several proposed gas and oil pipelines. Since 2010, the Unist'ot'en clan, members of the Wet'suwet'en Nation, have been reoccupying and re-establishing themselves on their ancestral lands in opposition to these projects. They have set up a camp on the GPS coordinates of the pipeline route as a way to impede the construction of any pipelines from crossing their territory, which they term as "occupied and un-ceded" as the tribe has never signed a treaty with the Government of Canada.

This resistance is part of a long history of struggles for territorial self-determination. In 1984, the Wet'suwet'en, together with the Gitksan, went to Court to assert their sovereignty, legal jurisdiction and aboriginal rights over the 58,000 square kilometres of their combined territory in British Colombia. The case eventually made it to the Supreme Court of Canada (Delgamuukw v. British Columbia, 1997) and was a landmark in several respects. It established that the Tribe's territorial sovereignty, pending proof of a surrender, by treaty, is a legitimate and outstanding constitutional question that still remains to be resolved by the Court. It was also significant as the first case that admitted oral histories as principal evidence.

These two moments must be seen within a greater narrative of indigenous resurgence and affirmation in Canada that indigenous scholars such as Taiake (2005), Coulthard (2014) and Simpson (2011) have elaborated on and which engage with social theories of justice. In particular they attack the "politics of recognition" and reconciliation as a remedy for colonial injustices and call for radical alternatives to colonial structures as pathways towards decolonization. This paper aims to bring this literature into conversation with that on environmental justice, employing the struggle of the Wet'suwet'ten tribe for selfdetermination and the transformative significance of the Unist'ot'en camp resistance as an informative case to probe some of the limits of EJ and social justice theory for a decolonial environmental justice. Through an analysis of the historical and current 
struggle of the Wet'suwet'en it examines what happens when Western law clashes with indigenous law and cosmo visions in the courtroom, and in the territory and asks, what if environmental justice was to take decolonization seriously? In doing so, it aims to advance both multidimensional theories of justice and the environmental justice literature.

The potentialities and the limits to decolonizing environmental justice will be explored in this article through five moves. Following this first introductory section, the second section discusses methods and positionality, the third section reviews the literature on EJ and indigenous peoples and engages with Nancy Fraser's trivalent theory of justice and her distinction between affirmative and transformative remedies in conversation with other social justice theorists (Young 2011) and gives some background on the Wet'sewet'en and indigenous territorial perspectives. The fourth section introduces the two case studies, initially examining the deployment of spatial tactics, direct action and performance in the Unist'ot'en camp as an example that transcends a state-centered and rights-based approach and secondly, the legal battle for recognition of territorial authority through the Delgamuukw court case as a means to trace the limits and potential of Western legal and political institutions to meeting indigenous demands.

In the discussion, I propose three dimensions that can inform a decolonizing environmental justice. I suggest that beyond distribution, participation and recognition, EJ must consider relational ontologies of nature, self-governing authority, and epistemic justice. The ideas developed contribute to the thorny questions of overlapping sovereignties, as well as broader questions over how relationships, ontologies and worldviews on nature can inform an ongoing transformation towards ecological and environmental justice.

\section{Methods and Positionality}

This work is part of a long history of scholar-activism around environmental justice issues, which includes the production of social justice documentary films, the creation of an online global atlas documenting resistance struggles globally and other journalistic 
and academic work within a praxis that attempts to combines engaged scholarship and activism. As an expatriate settler-Canadian, this project also represented a re-encounter for me with my own role as a settler and a renewed engagement with indigenous solidarity work in Canada after many years living abroad, and thus entailed a process of "unsettling" myself within a space of solidarity described by Tuck and Yang (2012) as "an uneasy, reserved and unsettled matter that neither reconciles present grievances nor forecloses future conflict."

Field work at the camp was carried out in the summer of 2014 while filming a social justice documentary film as a support and testimony for the camp. Five in-depth interviews were conducted with camp members and indigenous and settler activists at the camp. The resulting 20-minute film, Corridors of Resistance ${ }^{1}$, entailed minimal mediation so as to let the community speak for themselves. It has been circulated, used at solidarity events and translated to Spanish. Publications, documents and declarations from the camp were analysed, as well as documents and legal articles on the Delgamuukw case and this material and the interviews were later coded and analyzed for key themes and concepts - including territory, justice, rights, and nature.

Protocols followed included the reclaimed free prior and informed consent protocol designed by the Unist'ot'en as described in section four. This entailed an iterative process of questioning intentions, contributions and methods, repeated several times, first by email, upon arrival at the camp, and again during the process of drafting and reworking the text. The work has been further informed by work on the decolonization of methodologies (Smith 2013) and by guidelines for "political rigour" and radical reflexivity being developed by a collective of scholars within the auspices of a large international project on trans-disciplinary research. Drafts of this article were shared and discussed with the camp members who provided critiques and feedback that were integrated into the text. This led to further questions from the camp and a process of reflexivity on the use of the work, intentions behind it, the perceived audience and how it

${ }^{1}$ https://www.youtube.com/watch?v=ZDR11_Xw7ts 
would benefit their struggle. Beyond benefit to the camp, it is hoped that the documentation of this transformative praxis will serves to inform and inspire other struggles and that this paper and accompanying video and materials can contribute to networking and sharing knowledge between marginalized communities engaged in similar battles for environmental and social justice.

\section{Literature Review}

This work aims to disturb EJ literature by bringing it into conversation with epistemologies of the south, indigenous theorists and critical and indigenous legal studies. Scholarship on environmental justice has expanded from its initial US roots and emphasis on the spatial distribution of toxics, to increasingly recognize multiple spatialities and dimensions of environmental justice (Walker 2009, Holifield, Porter and Walker 2009, Newell 2005).The literature has also expanded geographically and thematically to examine a range of issues and justice claims within trans-national and intergenerational perspectives (Sikor and Newell 2014; Chatterton, Featherstone and Routledge 2013; Schlosberg 2013). However, we may explore whether environmental justice theories are able to respond to the subordination of Indigenous normativities and whether they are compatible with a decolonizing politics of justice.

This is important because Indigenous communities are at the forefront of struggles against land dispossession and environmental degradation globally. For example, in the Global Atlas of Environmental Justice (www.ejatlas.org) which documents 2500 cases of ecological conflicts, indigenous populations are present in $40 \%$ of cases (Temper et al 2018). An emerging body of literature in EJ research grapples with the unique political and cultural dynamics of indigenous communities (Warner 2015. Whyte 2016, Westra 2012; Vermeylen and Walker 2011) addressing issues such as collective claims to sovereignty; the need for new understandings of communal health and spiritual wellbeing related to the loss of sacred and cultural resources (Ranco et. Al 2011); and the need for a community-based, capabilities-centered conception of environmental justice (Schlosberg and Carruthers 2010). 
Scholars from a Latin American perspective have put forward the need for a decolonial environmental justice, often focusing on the need for inter-cultural communication (Rodriguez and Inturias 2018, Escobar), ontological politics (Blaser 2013, Escobar 2012) and the decolonization of knowledge and social relations. However, environmental justice literature in the Global North has engaged less with the colonial and epistemic roots of injustices, with some exceptions (Arn and Keeling 2009; Whyte 2016). Whyte (2016:192) for example, describes indigenous environmental injustice as occurring "when one society robs another society of the institutional and ecological conditions required for members of another society to experience the world in ways that motivate their engagement in the operation of systems of responsibilities." $\mathrm{He}$ suggests that such an indigenous conception of EJ serves to suggest very different solutions for remedying environmental injustices but does not clearly lay out what these are. This paper contributes to moving beyond colonial constructs in proposing remedies for environmental justice as experienced by indigenous communities.

This paper thus explores the opportunities and limitations of environmental justice theories for transformative politics and decolonizing practice in the settler-colonial context. To do so we engage with the trivalent framework of justice (distribution, recognition and participation) first developed by Fraser (1995) and extended to EJ by Schlosberg (2007), which has become canonical in the literature. It provides a useful framework for examining how these dimensions address or fail to address the demands put forward by a decolonizing environmental justice perspective and what dimensions need to be included or adapted to lead to transformative change.

\subsection{Beyond Distribution, Recognition and Participation}

Fraser (1995) initially put forward a bivalent theory of justice, pointing out that claims for recognition of cultural difference and group identity was supplanting class interest and calls for socio-economic redistribution as the chief medium of political mobilisation. She argued that cultural domination and material inequality should be seen as analytically 
distinct yet imbricated paradigms of injustice, with a dialectical relationship between them. Later, Fraser (2008) acknowledged the inadequacy of the binary recognition/distribution paradigm and added a third pillar -- "representation", arguing that representation-related injustices driven by "political voice-lessness," were becoming increasingly important in struggles for justice and democracy in a globalizing world and represent, through participation, the field of action upon which the other claims play out on.

In Fraser's view, the three types of injustices may be resolved in one of two ways: affirmatively or transformatively. Transformative remedies are associated with "correcting inequitable outcomes precisely by restructuring the underlying generative framework" (Fraser 2005:73), while affirmative remedies try to reduce inequalities without challenging the underlying social relations.

For example, affirmative redistributive remedies correct income inequality by transferring material resources to the maligned groups, for example through the social welfare state. However, these remedies tend to leave intact the conditions, such as the capitalist mode of production, that were responsible for generating income inequality in the first place. In contrast, transformative redistributive remedies are aimed at eradicating the origins of economic injustice and eliminating the root causes of economic inequality. They would include the transformation of basic economic structures and reorganization of the division of labour (Fraser, 1995).

In terms of ecological distribution (Martinez-Alier et al 2010), an EJ which aims for "equal rights and exposure to risk and pollution" such as the perspective advocated by the Environmental Protection Agency in the US is affirmative because it fails to explicitly demand a radical improvement in everyone's treatment and to address the social, political, economic, and cultural forces that produce environmental pollution (Pellow 2009). In contrast, the 17 principles of Environmental Justice declared by the First National People of Color Environmental Leadership Summit which demands, among other things, "the cessation of the production of all toxins, hazardous wastes, and 
radioactive materials, and that all past and current producers be held strictly accountable to the people for detoxification and the containment at the point of production," (www.ejnet.org) represents a transformative remedy.

Recognition is concerned with who is given respect and who is and is not valued, as well as questions such as "Who has standing? On what concerns? What are the legitimation processes by which social and symbolic meaning are attributed to these questions? What constitutes power, and what are the contexts with respect to those with power and those without?" (Agyeman et al. 2010; 8). Scholars have often highlighted the importance of the recognition paradigm as a way to understand the cultural impacts of indigenous environmental injustices (McGregor in Agyeman et al. 2010, Figueroa 2005, Porto and Pacheco 2009). However, recognition as an EJ issue is complicated as there are a range of claims regarding what should be recognized (Young 2011) as well as the contested meaning of recognition itself in practice, and the need for subjective experience therefore in defining it (Kompridis 2007).

Recognition can refer to the need for the injustice or form of violence itself to be recognized as such, by both those who experience it, as well as by others (Young 2011). Claims for recognition have also been made for territorial sovereignty, for ecological integrity (Pimentel et al 2000, Neimanis et al 2012) and "the recognition that all aspects of Creation are interrelated" (McGregor 2010: 36). While some argue for the need to extend recognition and participation to nature itself (Schlosberg 2007), it has not been clearly delineated how this would operate in practice and how liberal conceptions of justice can be transcended to incorporate such broader understandings of recognition.

A major gap in EJ literature on recognition concerns dominant conceptions of knowledge. This points to the absence of shared understandings of the grammar of justice, (the what, who and how) and acts as a fundamental impediment to operationalizing justice. This has been referred to as "epistemic justice" - which entails making visible and politically relevant ways of knowing that have been marginalized as a result of the imposition of a dominant knowledge system over others" (Widenhorn 2014; 
380).

Epistemic justice thus goes beyond procedural justice or participation as it entails defining the concepts and problems themselves and reminds us that knowledge itself is not neutral or objective but connected to power and must be seen through a historically distinct analysis to be understood. For example, liberal notions of justice and the legal system, are founded on "universal access" to rights grounded in a western knowledge system based on "objective" knowledge. However, these rights are linked to a specific understanding of the 'good life', freedom and happiness, and can close off other understandings and related emancipatory possibilities.

The epistemic and ontological violence perpetrated against non-occidental cultures operates such that even where the physical control of territories has ended, the cultural logic of colonialism still operates, and silences other ways of doing, being and knowing (Mignolo 2007; Escobar 2016; Maldonado-Torres 2007). Santos et al. (2007) call this the 'coloniality of knowledge': the hegemonic conception of modern scientific knowledge. Epistemic justice thus takes two main forms: testimonial and hermeneutical (Fricker 2007). Testimonial injustice occurs when a hearer discounts the credibility of a person's testimony on account of their social identity. Hermeneutical injustice arises when society lacks the interpretative resources to make sense of a speaker's experience, because that speaker has been marginalised in meaning-making activities. As Vermeylen (2013) highlights, stories and narrative are dialectic processes, imparted in a context of a transforming relationship between the elicitor and the narrator, the success of which will depend on the hearer's capacity and willingness to understand and respond to the validity claims raised.

As regards recognition, Fraser (1995) associates affirmative remedies with "mainstream multi-culturalism[...] which aims to redress disrespect while leaving intact both the contents of those identities and the group differentiations that underlie them". In contrast she associates transformative remedies with deconstruction and redressing disrespect by transforming the underlying cultural-valuational structure. For example, she uses the 
example of "queer politics" to explain how by destabilising existing group identities and differentiations, such as the homo/hetero binary, such remedies not only raise the selfesteem of members of currently disrespected groups, they change everyone's sense of self.

Finally, for Fraser, the normative foundation of justice is participation equality. According to this norm, justice requires a social arrangement that permit all (adult) members of society to interact with one another as peers (Fraser 2003, p.36). Fraser advocates for "a politics aimed at overcoming subordination by establishing the misrecognized party as a full member of society, capable of participating on a par with the rest." This entails representation so as to overcome barriers to political participation.

Potentially more relevant to indigenous peoples claiming sovereignty is what Fraser refers to "misframing", or meta-political injustice which result due to issues with the (geographical) scales which delimit the bounds of justice and to "the division of political space into bounded polities" that are drawn in such a way as to wrongly deny some people the chance to participate at all in its authorized contests over justice" (Fraser 2008:408). Yet her focus here remains on the global poor and those who are stateless. She does not address specifically the case of those who oppression is tied to the existence of the state itself.

This brief review, by bringing EJ into conversation with indigenous scholarship and perspectives on nature and territory, suggests the need to revise several widely held tenets within environmental justice theories and test their adequacy for settler-colonial contexts. The first is that the rights paradigm (and the legal arena) is the appropriate mechanism for seeking remedy for environmental justice (Gonzales 2013). Another is the assumption that a politics of recognition (directed towards the state) is a necessary and sometimes sufficient pre-condition to participatory and distributive environmental injustice (Turner 2006; Whyte 2011). Third is the universalist assumptions that inform political philosophy on environmental justice. 
The following sections presents the ontologies of nature and territory of the Wet'sewet'en and their engagements with the state and the legal regime to inform the discussion on how EJ can more meaningfully address these issues.

\subsection{Background - Visions of territory and governance of the Wet'sewet'en}

The Wet'sewet'en are an Athapaskan culture related to inland Carrier groups, and the name Wet'sewet'en (Witsuwit'en) means 'the people of the lower drainage" referring to their occupation on the tributaries of the Skeena River in the Bulkley Morice Watershed (Mills 1994, 37). The Wet'suwet'en people are governed by two primary systems: a hereditary system (represented by the Office of the Wet'suwet'en) composed of 5 clans: Gilseyhu (Big Frog), Laksilyu (Small Frog), Gitdumden (Wolf/Bear), Laksamshu (Fireweed) and Tsayu (Beaver clan). As well as a band-level system which consists of six bands (Moricetown Band, Burns Lake Band, Hagwilget Village Council, Nee Thai Buhn Band, Skin Tyee Nation, and Wet'suwet'en First Nation). The Unist'ot'en are members of the Gilseyhu (Big Frog Clan) and Moricetown band.2

The Wet'suwet'en are a matrilineal society whereby clans are further divided into kinbased groups known as Yikhs, often referred to as house groups, which function autonomously and have jurisdiction over their house territory. For the Wet'suwet'en, this jurisdiction is considered a responsibility rather than a right, with the hereditary chiefs entrusted with stewarding and caretaking the territory to ensure it will continue to produce game, fish, berries, and medicines to support the subsistence, trade, and customary needs of house members (Mills 1994; Mills and Overstall 1996). The

\footnotetext{
2 The council system was set up with the Indian act of 1876 to govern the reserves. The Unist'ot'en clan repudiates their authority, and while Delgamuukw affirms the traditional system of hereditary chiefs as those who can take decisions over the Wet'suwet'en territories, energy companies often negotiate with band councils even though they don't have the power to consent to development projects beyond the reserves. For example, Chevron has formed The First Nations Limited Partnership (http://bcfnlp.ca/ ) with band councils as the basis for an agreement on PTP. On Jan. 23, 2015, the Moricetown band_became the 16th band along the pipeline route to sign on to the partnership. Touted as a "\$500 million + commercial partnership by and for First Nations", the 16 bands will share 32 million Canadian dollars (U.S. \$24.6 million) once construction begins, as well as \$CA 10 million (\$7.7 million) per year while the pipeline is operating. Meanwhile on August 6, 2015, all five Unist'ot'en chiefs, along with four other Wet'suwet'en chiefs, signed the Unist'ot'en Declaration declaring that the land was unceded and that their consent was needed for any project on their territory.
} 
responsibilities of the chief to manage and harvest resources are validated through the feast system, the central governance institution of the Wet'suwet'en (Mills 1994). "It is in the feast that people are given their titles, their robes and their crests and the authority over the territory associated with those titles."

Similar to many First Nations in British Colombia, the Wet'suwet'en have never signed a treaty with Canada and this means their territory remains unceded. In the Royal Proclamation of 1763, King George III declared that title to Indian territory was not to be considered extinguished or transferred merely by conquest or occupation but only through voluntary cession. This Proclamation retains the status of constitutional law in Canada and means that the land title question for First Nations in B.C remains to be settled.

However, the territorial question brings to the fore the profound difference in vision between indigenous territorial relations and state forms of property (Thom 2014). Indigenous notions of territoriality unsettle the concept of territory in geography, which has recently been a focus of analysis (Painter 2010) and has been conceptualized as a "political technology" for the occupation and control of space and exercise of state power (Elden 2013). Such a conception does not account for the diversity of indigenous relationships between people and place. The disruption of indigenous relationships to land and the "epistemic, ontological, cosmological violence" continually re-asserted through colonization as land is remade into property (Tuck and Wang 2012, 5) is the cornerstone of the ongoing processes and structure of settler-colonialism.

Conversely, decolonization entails the reclamation of such relationships and the actual repatriation/unsettling of land. As Simpson (2014) asserts for the Mohawk "Their own object was and is territory in a material sense, their land - but also ideas, the past, the present, the future, their membership within the polity itself." Similarly, political ecologists in Latin America describe how the "territorial question" is being debated and inscribed in a tense political process as the confrontation of power strategies for the 
appropriation of nature3 (Porto-Gonçalves, 2004). They point to how cultural rights guide these processes of re-territorialization, leading to new material and symbolic forms of appropriation of nature and new meanings that stem from the local cosmogonies and socio-economic practices. Under this light, the territory is redefined as the summa of nature/culture power relations. Such contrasting ontological understandings of territory raise considerable challenges on how territorial jurisdiction with the state can be negotiated, without abstracting and articulating indigenous perspectives in a way that erases them, as we shall address in the next section.

\section{The politics of indigenous pipeline resistance}

\subsection{The Unist'ot'en "checkpoint"}

"We will not remove our Gateway (not a blockade). A gateway into understanding truth and meaningful decolonization."

- Unist'ot'en Camp

The first confrontation of the Unist'ot'en Clan with the Pacific Trails Pipeline (PTP) natural gas pipeline dates from November 2011 when camp members escorted drillers and other PTP employees off their territories. Hereditary Chief Toghestiy again evicted surveyors from their territory on 20 November 2012, by presenting them with an eagle feather, the first and only traditional notice of trespass. The surveyors were ordered to leave the territory and the road entering into the territory was been closed to all industry activities.

On 27 November 2012, solidarity protests for the camp and against fracking were held in 13 cities, from California to Toronto and across British Colombia, and representatives of the Wet'suwet'en delivered eviction notices to Apache Oil and Enbridge stating that the companies “are not permitted onto unceded lands of the Wet'suwet'en; are not permitted

3 This is perhaps best expressed in the words of the seringeuros of Brazil, quoted bv Porto-Goncalves: "nosotros no queremos tierra, nosotros queremos territorio". We don't want the land - we want the territory 
to place their greed ahead of Indigenous self-determination; are not permitted to destroy and exploit the lands; are not permitted to disregard the safety and health of communities;[and] are not permitted to disregard [our] Law!" Freda Huson, spokeswoman for the clan, had written a letter "To the illegitimate colonial governments of Canada and British Columbia, and to all parties involved in the proposed PTP project that stated "This letter is to issue a warning of trespass to those companies associated with the PTP industrial extraction project and against any affiliates and contractors infringing upon traditional Wet'suwet'en territory...any further incursion into their territory [will be interpreted]as an act of aggression against their sovereignty and that violators will be held accountable."

Following this, the first cabin of the camp, home of Freda Huson, a member of the Unist'ot'en house of the Gilseyhu, (Big Frog) clan, and her husband Toghestiy, of the nearby Likhts'amisyu (Fireweed) clan, was built directly on the GPS coordinates of the proposed route of the Pacific Trails Pipeline (PTP), which they refer to as "the trailblazer of the prospective energy corridor".

The struggle of the Unist'ot'en must be seen in a broader context of politics of resistance against pipeline projects in Canada and in British Colombia led by First Nations (Scott 2013, McCreary and Milligan 2014). The Unist'ot'en are one node in a networked resistance movement opposing these pipelines, petro-infrastructure and "fossil capitalism" in Canada composed of environmental organizations, affected citizens and First Nations (Scott 2013). These struggles, fought on many fronts, including in the courts, through legislative means, in the streets and on the land, are claiming victories. The most recent being the cancellation of the Enbridge pipeline after the courts ruled that the government failed in upholding its constitutional duty to consult First Nations who would be affected by the pipeline.

Considerable geo-political stakes and multi-billion dollar investments are at play here, as pipeline infrastructure is key to Canadian Government and industry plans to unlock the vast energy resources in the Alberta tar sands and the fracking fields in North Eastern 
British Columbia (BC) and deliver them to global markets through ports in Kitimat and Prince Rupert on BC's West coast. This is part of plans on the part of the province of BC to become a major exporter of shale gas from Hydraulic Fracturing fields in the Horn area of British Colombia through a liquified natural gas (LNG) economic strategy estimated to be worth some US $\$ 78$ billion. On the line are billions of dollars and 19 LNG projects, including five natural gas pipelines, and three LNG facilities planned to be in operation by 2020 . These projects make up what has been termed a planned 'energy corridor', designed ultimately to unlock the tar sands and allow them to be marketed globally without first passing through the US (McCreary and Milligan 2014).

While the Enbridge oil pipeline has generated heated opposition from many of the 50 indigenous territories whose lands it would cross, opposition to "natural" gas pipelines has generally been more muted. This may be partly because their concerns regarding the distribution of risk has been assuaged as many communities are told that in case of a spill the gas would simply evaporate. In contrast, the position of the Unist'ot'en camp is counter to a NIMBY approach that transcends concerns for distributive impacts on their territory alone (Neville and Weinthall 2016). According to them, their resistance is in solidarity with communities in the North-East of the province where the extraction would take place, coastal communities impacted by export terminals, as well as communities from the tar sands, as well as other marginalized communities impacted by climate change. Further, they see the defense of territory within a broader process of healing the trauma of colonization for indigenous peoples within Canada and within a broader global perspective, as described further in section 5 . This positioning and their complete opposition to all pipelines - existing, proposed or approved to expand - means the camp has wide support, and has become a symbol against extractivism (Acosta 2013).

The camp's presence seems to have contributed to several significant victories in terms of discouraging investment with up to 5 of 7 proposed pipeline projects being canceled or on hold as of October 2017. The PTP project was initially shared by EOG Resources, Encana Corp., and majority owner Apache corp. of Houston, Texas. In 2013, EOG and Encana sold their shares in the project to Chevron Canada, a subsidiary of Chevron 
Corporation, which moved into a 50\% ownership position along with Apache. In 2014, Apache also pulled out and PTP is currently on hold as Chevron does not have a new partner and the project does not have Asian buyers lined up. This recent withdrawal of Apache was heralded as their victory on the Unist'ot'en website, feting that all of the original investors (Encana, EOG and now Apache) have now bailed on the project. Several competing projects are still in the "pipeline" and trying to gain access to the territory-foremost among these is Coastal Gaslink, a $650 \mathrm{~km}$ natural gas pipeline that TransCanada is building connected to the CA $\$ 12$ billion "LNG Canada" terminal in Kitimat, in parntnership with Shell, PetroChina, Korea Gas and Mitsubishi.

\subsection{Reimagined Free Prior and Informed Consent}

The checkpoint in the Unist'ot'en camp is controlled via a wooden bridge bridge across the Wedzin Kwah (Morice River), 66 kilometers up a logging road from Houston, British Columbia. This river serves as a border between Canada and the traditional territory of the Unist'ot'en. The blockade is marked by a large, painted-plywood sign that reads "STOP. No access without prior consent".

To cross the bridge and enter the camp, every person who enters must go through a "Reimagined Free Prior and Informed Consent (RFPIC)" protocol that has been established by the Unist'ot'en camp collective. According to the Unistot'en website "In ancient times and even today... in community resistance building gatherings, there exists Protocols where visiting peoples have shown who they are in relation to asking permission to enter the Traditional Lands from the Traditional Chiefs and Matriarchs of the hosting lands." (Unist'ot'en ND)

The protocol entails five questions that are sent to visitors when they give advance notice of their arrival.

1. Who are you?

2. Where are you from? 
3. What is your purpose in coming here?

4. Do you work for Industry or Government that is destroying our lands.

5. How will your visit benefit the Unist'ot'en people?

According to the camp members, the RFPIC should be seen as an act of reclamation of the FPIC process that has been "taken... strangle hold by the Corporations, NGO's, Governments and other Colonial Bodies" (Unist'ot'en ND). This is because FPIC is increasingly used as a mechanism to facilitate and legitimate development projects "where the ' $\mathrm{C}$ ' in FPIC is increasingly redefined as 'consultation', precisely because the principle of consent, if taken seriously, does imply the right to say 'no' and the power to veto." (Franco 2014) Counter to this appropriation, the Unist'ot'en claim that it is not a new process but based on Traditional Laws that were asserted via protocols like this on the lands for thousands of years.

The Wet'suwet'en also had to present themselves as such when travelling to neighbouring peoples' lands to conduct trade, protocols, build and maintain peace, assist with allies' battles, and attain resources or trade work. Visiting nations would be required to dance their stories to show to the host nations that they truly are who they say they are (as the dance would have been seen through historical trade relations). (Unist'ot'en ND)

In this way, the RFPIC is a living breathing (re)assertion of the Traditional Laws of the Wet'suwet'en. According to their website (Unist'ot'en ND); “Free Prior and Informed Consent is not gone, lost or eroded. It has been asleep. The knowledge of conducting them is still active. It must be asserted by the Indigenous Peoples' of these lands. It is not a mere document at the UN office awaiting to be implemented by statism. It is living breathing protocols that must be asserted by peoples who live off the land, connecting to the spirit of the ancestors and upholding Natural Laws."

The RFPIC protocol is part of a long history of occupation through physical means, through the use of checkpoints and controls, which has been a feature of cultural norms 
and values for First Nations in Canada for a long time (Borrows 2005). The checkpoint or blockade is a spatial tactic of direct action resistance, that is both instrumental as well as symbolic. Instrumentally, "The blockade is ... used to regulate movement where movement itself is in dispute. Blockade is frequently seen as a means of physically halting "the massive and unsustainable out-movement of capital and commodities from traditional territories" (Blomley 1996, 14). Blockades are particularly effective in this regard in Canada (Wilkes et al 2010) due to the particular geography of colonization in Canada, whereby its low-density population and rugged terrain mean that pockets of unprocessed resources such as timber or metals are hauled out long distances over few transport connections (Blomley 1996). First Nations territories maintain privileged access to these arteries of economic flows and exercise incredible leverage to put at risk the "critical infrastructure" that transports natural resources and manufactured goods from mines, oil fields, hydro-electric facilities and factories to international markets (Pasternak 2013). The assertion of territorial control that disrupt capitalist extractivist activities should also be seen as a struggle against the extractivist model itself.

Blomley (p.14) argues, that blocking the flow of resources is what invests the blockade with its tremendous strategic power and that the blockade also holds a symbolic effect "to the extent that it marks out two spaces... (mapping) out a boundary and, in so doing, distinguishes an "Indian" space from a "Euro-Canadian" space." This demarcation is an act of defiance, yet beyond the disruption of the flows of capitalism and the denial of the movement of resources out of the territory, the blockade can (temporarily in most cases but in some cases for extended periods) create a space for the control and practice of indigenous economic and political authority in the face of the cultural and economic dislocation forced upon them. In the case of the Unist'ot'en it has enabled the creation of a 'safe haven' (Anguelovski 2013) where they may enact their shared aspirations and identity, and assert their sovereignty over their lands.

The process of RFPIC as enacted in the camp should also be considered what Kennedy (2002), a legal scholar critical of rights-based approaches, has described as the disruption of the oppressive exercise of legal power through engaging in a series of small scale, $a d$ 
hoc transgressive performances, in an attempt to subvert or dismantle existing social structures (Kennedy 2002). This form of "tactical guerrilla warfare" at the same time opens pathways to indigenous affirmation and "self-recognition". It forecloses the continual expansion of state authority to designate specifically bounded forms of Indigeneity, opening up new "indigenous ways of becoming”.

Moreover, the assertion of unilateral sovereignty that the RFPIC entails redraws the frames of representation - in this case shifting the "who" in the case of who is the sovereign who is granting recognition/access to the territory. By establishing consensual relations on their own terms, the RFPIC stakes out a space for political sovereignty defined by their own legal interpretations and authority. This process of assertion of sovereignty thus offers a more transformative remedy to the marginalization of indigenous peoples and perspectives than the participatory parity offered by Fraser. We return to this in the discussion.

Finally, the RFPIC questions the ontology of what consent is and posits it as a process that each community must construct. In this way, they address the procedural questions of justice - what consent is and what it means and the need for the community itself to define consent.

\subsection{Delgamuukw and the Legal approach}

We are not interested in asserting aboriginal rights. We are here to discuss territory and authority. When this case ends and the package has been unwrapped, it will have to be our ownership and our jurisdiction under our law that is on the table.

- Delgam Uukw

The resistance of the Unist'ot'en needs to be seen within a long history of creative resistance of the Wet'suwet'en against colonialism. Along with the Gitxsan First Nation they blockaded logging in their traditional territory in the late 1980s, an action which 
culminated in the groundbreaking Delgamuukw court case whereby in 1984, the GitksanWet'suwet'en went to Court to assert their sovereignty, legal jurisdiction and aboriginal rights over some 58,000 square kilometres of their territory in British Colombia (Borrows 1999).

In Delgamuukw, the Gitxsan and Wetsuwet'en demanded recognition of their unextinguished jurisdiction over the land. This claim was based on the fact that they had never signed any land treaties with the governments of Canada and therefore that they had never ceded title to their traditional territories as per the Royal Proclamation of 17634. In the absence of a ratified treaty and having never been conquered in war, the Gitxsan and Wetsuwet'en thus retained title and jurisdiction over their land, according to Canadian law.

Begun in 1984, the case first went before the Supreme Court of British Columbia in 1987 (Delgamuukw: $S C B C$ ), where it was dismissed by Chief Justice Allan McEachern in 1991. The ruling was then appealed in the British Columbia Court of Appeal (Delgamuиkw: BCCA) and eventually went to the Supreme Court of Canada (Delgamuukw: SCR). The final decision was handed down by Supreme Court Chief Justice Antonio Lamer in 1997 and is considered a landmark ruling for Indigenous land claims. Despite its very qualified affirmation and diverging views on what was accomplished (Borrows 1999, Pasternak 2014, Napoleon 2005), it established that the Tribe's territorial sovereignty, pending proof of surrender, by treaty, is a legitimate and outstanding constitutional question that still remains to be resolved by the court. Perhaps the most significant outcome of the case was that after initial objections, the Gitksan and Wet'suwet'en were able to use their oral histories as principal evidence in the case. In order to demonstrate their "long-time use, occupation, possession and administration" of the contested land, they relied on "tremendous quantities of intensely detailed evidence of their languages, genealogies, customs and oral histories," which

\footnotetext{
4 The force and legitimacy of the Royal Proclamation had just recently been re-affirmed by its incorporation into section 35 the Canadian constitution in 1982.
} 
demonstrated their deep and enduring social, cultural and historical connections to their territory (Daly 2007; Vermeylen 2013).

In the case of the Wet'suwet'en, the oral history is transmitted through the "Kungax", a spiritual song or dance or performance where the "recital[s] of the most important laws, history, traditions and traditional territory of a House...is repeated, performed and authenticated at important feasts." In the case of the Gitksan, it is through the adaawk. It was in the feast hall where for millennia they would tell and retell their stories, pass on important histories, songs, crests, lands, ranks, and properties from one generation to the next, and identify their territories to remind themselves of the sacred connection that they have with their lands. (Napoleon 2013, Borrows 1999)

Richard Overstall (2004) explains how in the case of the Gitsxan, these histories serve as an embedded law that evolved as the result of people observing the consequences of their behaviour over time. Behaviour that was disrespectful of spirits, animals, and the others, and the consequences of it were recorded in adaawk, especially if the behaviour alters a lineage's relationship with its territory. The adaawk thus served as legal precedents to inform later conduct.

The plaintiffs argued that understanding the Gitxsan and Wetsuwet'en argument for jurisdiction requires an understanding of their cultures' views of the world through these oral histories. While property does exist in Gitxsan and Wetsuwet'en culture, it is expressed in terms that may be lost in translation for an observer not intimate with the territory. These histories lay out a series of relationships with the territory, rather that one of simple ownership as understood by Western property rights. Aboriginal property rights concern use, not exploitation or extraction (Mills 2010). As she explains: "The Witsuwit'en believe that people may kill the animals as long as they treat them with respect. If they do not, the animals will not reincarnate or allow people to take them (Mills; 1994; 157)." Laws laid down in the Kungax and the Adaawk also record when houses can pick berries, fish, among others. (Morden 2015)

By creating a space within the court-room where indigenous narratives were able to gain 
equal legitimacy to settler narratives, through the use of their traditional spellings, regalia and songs, the Delgamuukw trial served to deconstruct the courtroom in a performative way, recreating and redraw the boundaries of the colonial system that is the court-room (Napoleon 2013, Borrows 1999). In this way, the Delgamuukw trial served as a transformative vehicle for cultural politics and opened up a space for decolonizing practices (Mills 1994). At the same time, it also revealed some of the limitations of the formal justice system as regards the recognition of indigenous sovereignty as well as the recognition of a relational ontology with nature as the next section argues.

\section{Discussion - Unsettling environmental justice}

This paper aims to contribute to a disturbance of Western ontologies and epistemologies of Environmental Justice with the aim of charting more emancipatory futures. While the theories of EJ proposed by Schlosberg and Fraser have made tremendous contributions towards a more pluralist understanding of justice; such frameworks in their attempt to be inclusive and universal can also lead to foreclosing other understandings of what justice is, who the subjects of justice should be and how it should be delivered.

A decolonial analysis informed by the two moments of Wet'sewet'ten history explored here suggest limits and adaptations to the trivalent framework based on recognition, participation and distribution. I propose three pillars of a de-colonial environmental justice. I argue that rather than simply participation, justice must include self-governing authority; that rather than distribution (of nature), environmental justice calls for breaking down the dualism between humans and nature, and beyond recognition, what is needed is epistemic justice and self-affirmation. I question the capacity of the state and legal framework for accommodating such a decolonial and transformative environmental justice and instead propose that direct action, and assertion of responsibility and care may serve as more effective tools of resistance.

These insights are not only relevant for an environmental justice that takes decolonization and the claims of indigenous peoples seriously but can also contribute towards a more 
radical and potentially emancipatory environmental justice that can inform struggles, help hone tools of resistance and transformatively rethink human-nature relationships.

\subsection{Beyond Participation --- Self-governing authority}

The standard narrative in EJ is that justice requires fair and meaningful participation by those affected. For Fraser (2008) this entails the need for "participatory parity" - which entails inclusion of all "subjects of justice" understood as those jointly subjected to a structure of governance, which sets the ground rules that govern their interaction. (Fraser $2008 ; 65)$.

Participatory parity therefore primarily concerns itself with how to build inclusion within existing governance structures. Fraser's theory contains important elements of reflexive openness which allows discussion around who the subjects of justice are in each context. However the framework is still rooted in Western thought and experience and is designed to deal primarily with claims of exclusion - those where the denial of participation is the main complaint. It is a less appropriate fit for the settler-colonial context, whereby the problem is precisely that indigenous peoples have to address their claims within a sovereignty they do not recognize. Rather than participation, what they are seeking is political and social exemption. They are not seeking participation but recognition of their sovereignty and their self-governing authority. Westra (1999) thus differentiates between black communities in the US who demanded an end to segregation as a result of being forcibly excluded from society - to be treated as equals - and aboriginal peoples in Canada who have been forcibly included and assimilated into society through discriminatory laws. In this case, she argues, granting rights is not only insufficient, but simply wrong.

The limits to participatory parity are well demonstrated by the Delgamuukw case where the state framework was unable to provide a mechanism for resolving the demand for indigenous self-determination. As Coulthard (2014: 36) argues, the settler state does not constitute a legitimate framework within which indigenous peoples may be more justly 
included. Instead, the Delgamuukw case brought into question the court's very authority. Borrows (1999) refers to this as "Sovereignty's Alchemy”, asking "What alchemy transmutes the basis of Aboriginal possession into the golden bedrock of Crown title?" (p. 558), referring to the fact that the underlying injustice is the assumption of the sovereign power as the foundation of the legal order itself (Muldoon 2015). As Coulthard $(2014 ; 36)$ argues; participation within the Canadian legal system leaves intact two primary features of colonial domination that indigenous assertions of nationhood call into question: the legitimacy of the settler state's claim to sovereignty over their territories and the normative status of the state-form as an appropriate mode of governance on the other.

Instead of participation and inclusion, justice for occupied and indigenous peoples calls for interrogating the mapping of political space and inclusion within the frame of the territorial state itself. The terms of participation, and the subjects of justice are misframed. This implies the need to decolonize law and to deconstruct the state's grounds to inaugurate law on lands acquired through colonial settlement (Pasternak 2014). It also calls for decolonizing participatory parity, which entails reframing and questioning the authority of the state itself as the governance framework and looking beyond standard liberal frames of justice to acknowledge that the existing international system of nationstates cannot meet indigenous demands for self-determination, and that a commitment to justice for indigenous peoples may entail calling those state-systems into question (Young 2000). Because the state is often the key actor pushing extractive projects, decentering the state and envisioning governance beyond its confines is an important contribution from indigenous thought that can productively unsettle EJ.

\subsection{Beyond Distribution --- Destabilization of the human / nature dualism}

Environmental justice from the outset was concerned with the distribution of environmental resources and burdens. This perspective relies on a conception of nature as a passive object that can be more justly and equitatively distributed among human populations through different property rights, allocations, etc. Such a perspective on distribution is incompatible with indigenous conceptions of nature and on human- 
ecological relationships that call into question the view of the environment as a commodity that can be owned or traded.

The Wet'suwet'en and Gitxsan cosmology views humans as being fundamentally interconnected with their ecology. The plaintiffs, Gisday Wa and Delgam Uukw, describe in their opening address a view that understands the world to be a differentiated unity, of which humans are only one part. There is no strict human/ nature dualism in this view (Wa and Uukw 1992). They wrote: "The Western world-view sees the essential and primary interactions as being those between human beings. To the Gitksan and Wet'suwet'en, human beings are part of an interacting continuum, which includes animals and spirits. Animals and fish are viewed as members of societies, which have intelligence and power, and can influence the course of events in terms of their interrelationship with human beings."

This relational perspective on nature sees human and non-human living beings as well as inanimate objects, within a matrix of relations, "backward and forward in time, laterally in the present" (Kneen 2015, 33). A relational ontology, summed up by the indigenous prayer phrase "All my relations" restores agency and subjectivity to nature. In indigenous legal tradition it is often expressed as "natural law": laws that are in keeping with the laws of the natural world (Westra 2012). According to natural law, relationships with nature are what define one's responsibilities to them. Thus instead of distribution of nature, the emphasis is on the mutual relations based on reciprocity and care.

Such an understanding of nature is extremely difficult to integrate into Western legal institutions for delivering environmental justice. The natural law of indigenous legal tradition, as well as Western law, are both based on a worldview and an understanding of how humans are (e.g., individual, competitive, communal, etc.) and how they relate to the larger world, as well as to non-human life forms (Napoleon 2013). The testimony of Delga Uukw and Nisgay Wa Uukw in the Delgamuukw case aimed to unsettle the Western idea of ownership and jurisdiction over land and resources (Bryan 2000) and 
demanded a destabilizing of the nature/culture binary that Western law is built on. This destabilization fits closely to the deconstructive cultural politics as described by Fraser (1995). It contributed to transforming the underlying cultural-valuational structure by destabilising identities and our own understanding of what it means to be human.

However, the court was not able to "recognize nature and the Other" in the relational perspective that the plaintiffs asked because the legal liberal tradition is unable to recognize indigenous relationship to land and nature other than through its own conceptions. This point is underlined by indigenous legal scholar Val Napoleon (2005) who explains that "The Court was not able to hear or accept the adaawk as presented - a legal and political institution rather than a simple cultural artefact or chronological history record. The forms of expression, symbolism, and inter-connections between the worlds of spirits, humans, and animals proved to be beyond the grasp of the trial judge".

For indigenous peoples in the settler colonial context, transformative redistributive remedies would go even further to confront the material conditions that they face within colonialism and would challenge western notions of property and distribution altogether. are forced to argue in courts that it is "their" land. What they cannot question within this system is the presumed relationship between peoples and land. That is, should land be a commodity to be controlled and owned by peoples?"

\subsection{Epistemic Justice}

Epistemic justice entails overcoming barriers for alternative forms of being and seeing the world to be recognized as valid and valuable knowledge and includes the even greater challenge of translating this into real policy and practice and social justice.

For example, relational ontologies and a destabilization and reconceptualization of the nature-culture binary (Plumwood 2004) are increasingly finding a place in initiatives to imbue Mother Nature with rights such as in the Bolivian and Ecuadorean constitutions. Yet there remain considerable challenges in theory, policy and law to dissolving this 
"ontological divide" 5 and numerous tensions emerge in the translation of indigenous ethics of care into legal and policy frameworks, as several authors have documented in the case of rights of nature (Arsel 2012; Fish 2013).

The integration of indigenous philosophies into hegemonic institutions can often lead to distortion, erasure and co-optation, a new form of epistemic extractivism and violence. For example, Widenhorn (2014) examined the mobilization of diverse actors of the concept of Buen Vivir, finding that the political act of translation served to transform "buen vivir into an object of knowledge detached from the knowledge holder." Through this, "the inherently relational character of Andean cosmovision was lost... whereas modern rationality was reaffirmed." She points to the gap between concept and reality and the tension between the need to make marginalized knowledges politically relevant, and the danger of erasing, co-opting and distorting these knowledge systems through the very act of doing so.

On the other hand, Valladares and Boelens (2017) explore the rights of nature discourse as an "epistemic pact" that can serve as a tool for re-politicizing the environmental debate by challenging the dominant mono-cultural, functionalist and extractivist notion of nature, defined by capitalism and science." They suggest that the political radicalism implied by this act of intercultural translation can lead to the creation of new alliances for territorial defense.

This leads to the question of how the recognition and participation of nature that some scholars (Nussbaum 1997, Schlosberg 2007) have been claiming for can be done in an epistemically just way? Can public policy "translate" concepts such as rights of nature, indigenous self-determination, responsibility, into real justice? What are the limitations for these claims as tools of resistance and how can epistemic justice be enacted by those claiming it?

5

See O'Neill (2006) for a discussion on The question of "who speaks for nature" for a discussion of the political implications of representing nature's interests as well as Castree's (2003) discussion on moving towards a politics of politics of socionatural hybridity. 
These questions would require more space to treat in depth, yet the case study suggests that moving towards epistemic justice requires on one hand, the opening up of concepts of nature and meaningful intercultural communication. The challenge for transformative epistemic justice here is not in translating indigenous concepts into terms comprehensible to liberal legal traditions but rather further developing through education, intercultural communication and listening, the interpretative "hermeneutical" resources to make sense of indigenous experience and perspectives. From here may emerge the possibility to transcend colonial and liberal constructs and open other worlds and other relationships with land, territory and nature.

The Unist'ot'en enactment of epistemic justice rests on questioning the knowledge structures through which decisions are made themselves; and creating and asserting their own processes and practices relying on their own knowledge, language and ways of seeing and being the world. This includes both politics of refusal (Simpson 2014) as well as healing and sharing to transform the capacity of others to hear. Most importantly beyond discourse it involves action and lived practice.

\subsection{Beyond Recognition: Rights v. Geographies of responsibility}

These are not resources - these are life-forms that we have access to. Our laws are our responsibilities. The way we harvest salmon is our living law.

- Unist'ot'en Camp

The Unist'ot'en checkpoint demonstrates a very different approach to the politics of recognition. Instead of appealing outwards, its aim is to create a space for what Coulthard (2015) refers to as "self-recognition" and indigenous re-affirmation. In this newly reclaimed space, the Unist'ot'en camp members have been able to assert their own legal understandings, and to live their concept of justice through practice, through enactment and through antagonistic politics that disrupt the economic and social logic and production of settler colonial power. 
The Unist'ot'en camp members reject a rights-based discourse that can only be accorded to them by what they perceive as an occupying power, and actively assert their responsibilities to the territory and their ancestral and natural law. According to the camp members, as warriors, they hold a sacred responsibility for all life in their territories. This is based on the concept of stewardship, whereby the warriors are managing the land because of their dependency on it, because of its intrinsic value as well as on behalf of the unborn future generations. Rather than speak about "rights" to fish they refuse to let their responsibility to the river to be diminished.

This assertion of responsibility through active presence is premised on self-actualization, direct action and the resurgence of cultural practices through antagonistic politics.

Environmental justice has always been about resistance, about continual repolitization of the environment, of redefining and expanding the concept of nature, and about reconnecting to place and territory. The space created by resistance camps such as the Unist'ot'en camp becomes a fervent space for transforming the collective imaginary and the hermeneutical capacity of the many visitors.

\section{Conclusion}

This paper has drawn from the Delgamuukw case and the Unist' ot 'en camp to challenge hegemonic theories of environmental justice and propose ones that can be mobilized for decolonization practices. Through examination of the Delgamuukw case, the possibilities and limits to recognition through the mechanisms of the state, as previously laid out by indigenous scholars (Muldoon 2005, Borrows 1999, Coulthard 2014) were outlined. In this paper a proposal for a decolonizing Environmental Justice in the settler-colonial context was put forward, based on the pillars of self-governing authority, the undoing of the ontology of land as property, and epistemic justice.

"You may justly ask, as a white settler on stolen land, who are you to write about this? Or 
to return to the fifth question of the protocol - how will my visit and this work benefit the Unist'ot'en? As a non-indigenous researcher, can this work contribute to actual and meaningful decolonization?

The honest and somewhat uncomfortable answer is perhaps not much or not directly. Beyond the theoretical, this paper argues for the need for direct action and endeavors to prompt readers to take action. Camp members say that the camp is not a blockade, but instead a gateway to understanding truth and meaningful decolonization. This work aims to reflect my own journey through this gateway and my personal transformation, and the continuing unlearning and undoing of my own settler-colonial mentality. At the Unist'ot'en camp, I became more conscious of my own accountability as a settler and cognizant of concrete actions I could take in solidarity and support of the political goal of decolonization. On the Wedzin Kwa with the Unist'ot'en and their supporters, decolonization moved from the theoretical to a lived reality that appeared possible to achieve and actionable in the present. My aim is to contribute to building this imaginary. Decolonization calls for an abolition of property relations as we know them and a renewal of our relationship with nature. It would be uncomfortable and unsettling, but it is imperative. The question now is how to listen and how to learn from indigenous struggles such as the Unist'ot'en to assert our own responsibility as indigenous and nonindigenous allies to make it happen.

\section{References}

Acosta, A.2013. 'Extractivism and Neoextractivism: Two sides of the same curse', in Lang, M. and Mokrani, D. (eds.) Beyond Development: Alternative visions from Latin America, pp. 61-86, Quito: Rosa Luxemburg Foundation, and Amsterdam: Transnational Institute.

Agyeman, J., Cole, P. Haluza-DeLay, R., O'Riley, P. 2010. Speaking for Ourselves: Environmental Justice in Canada. UBC Press.

Anguelovski, I. 2013. "From Environmental Trauma to Safe Haven: Place Attachment and Place Remaking in Three Marginalized Neighborhoods of Barcelona, Boston, 
and Havana." City \& Community 12 (3): 211-37. doi:10.1111/cico.12026.

Arsel, M., 2012. Between 'Marx and markets'? The state, the 'left turn'and nature in Ecuador. Tijdschrift voor economische en sociale geografie, 103(2), pp.150-163.

Blomley, N. 1996. “'Shut the Province Down': First Nations Blockades in British Columbia, 1984-1995.” BC Studies: The British Columbian Quarterly, no. 111: $5-35$.

Borrows, J., 2005. Crown and Aboriginal occupations of land: A history \& comparison. Ipperwash Inquiry.

Borrows, J. 1999. “Sovereignty's Alchemy: An Analysis of Delgamuukw v. British Columbia.” Osgoode Hall LJ 37: 537.

Borrows, J. 2001. 'Listening for Change: the Courts and Oral Tradition' 39/1 Osgoode Hall Law Journal 1 (2001).

Bryan, B. 2000. "Property as Ontology: On Aboriginal and English Understandings of Ownership." Canadian Journal of Law and Jurisprudence 13: 3.

Castree, N. 2003. Environmental issues: relational ontologies and hybrid politics. Progress in Human Geography: an international review of geographical work in the social sciences and humanities, 27 (2), 203-211.

Chatterton, P. Featherstone, D. and Routledge, P. 2013. "Articulating Climate Justice in Copenhagen: Antagonism, the Commons, and Solidarity.” Antipode 45 (3): 60220. doi:10.1111/j.1467-8330.2012.01025.x.

Coulthard, G. S. 2014. Red Skin, White Masks: Rejecting the Colonial Politics of Recognition. University of Minnesota Press. http://www.jstor.org/stable/10.5749/j.ctt9qh3cv.

Daly, R. 2007. Our Box Was Full: An Ethnography for the Delgamuukw Plaintiffs. UBC Press.

Delgamuukw v. British Columbia, (1997) 3 S.C.R. 1010

Delgamuukw v. British Columbia (1993), 104 D.L.R. (4th) 470 at 608 (B.C. C.A.), Lambert J.A.

Delgamuukv v. British Columbia (1991), 79 D.L.R. (4th) 185 at 278 (B.C. S.C.), McEachern C.J.

Escobar, A., 2012. Notes on the Ontology of Design. In Sawyer Seminar, Indigenous 
Cosmopolitics: Dialogues about the Reconstitution of Worlds, organized by Marisol de La Cadena and Mario Blaser, October (Vol. 30).

Escobar, A., 2011. Encountering development: The making and unmaking of the Third World. Princeton University Press.

Figueroa, R.M. 2005. "Bivalent Environmental Justice and the Culture of Poverty." Rutgers JL \& Pub. Pol'y 1: 27-43.

Fish, L., 2013. Homogenizing community, homogenizing nature: An analysis of conflicting rights in the rights of nature debate. Stanford Undergraduate Research Journal, 12, pp.6-11.

Franco, J. 2014. Reclaiming Free Prior and Informed Consent (FPIC) in the Context of Global Land Grabs. Amsterdam: Transnational Institute. http://landjustice4wa.org/wp-content/uploads/2014/08/reclaiming_fpic_0.pdf.

Fraser, N. 1995. "From Redistribution to Recognition? Dilemmas of Justice in A'postSocialist'age." New Left Review, 68-68.

—. 2008. "Abnormal Justice." Critical Inquiry 34 (3): 393-422.

—. 2010. "Who Counts? Dilemmas of Justice in a Postwestphalian World." Antipode 41 (January): 281-97. doi:10.1111/j.1467-8330.2009.00726.x.

Fraser, N. and A. Honeth. 2003. Redistribution or Recognition: A Philosophical Exchange. London: Verso.

Fricker, M., 2007. Epistemic injustice: Power and the ethics of knowing. Oxford University Press.Walker, G. 2009. "Beyond Distribution and Proximity: Exploring the Multiple Spatialities of Environmental Justice." Antipode 41 (4): 614-36.

Holifield, R., Porter, M. and Walker, G. 2009. "Introduction Spaces of Environmental Justice: Frameworks for Critical Engagement." Antipode 41 (4): 591-612.

Keeling, A. and Sandlos, J., 2009. Environmental justice goes underground? Historical notes from Canada's northern mining frontier. Environmental Justice, 2(3), pp.117-125.

Kennedy, D. 2002. "The Critique of Rights in Critical Legal Studies." Left Legalism/left Critique 178: 216.

Kneen, B. 2015. "Disconnecting the Dots: Boundaries and Rights." Accessed May 26. 
http://www.yale.edu/agrarianstudies/colloqpapers/02kneen.pdf.

Kompridis, N., 2007. Struggling over the Meaning of Recognition: A Matter of Identity, Justice, or Freedom? European Journal of Political Theory, 6(3), pp.277-289.

Maldonado-Torres, N., 2007. On the coloniality of being: Contributions to the development of a concept. Cultural studies, 21(2-3), pp.240-270.

McCreary, T.A., and Milligan, R.A. 2014. "Pipelines, Permits, and Protests: Carrier Sekani Encounters with the Enbridge Northern Gateway Project." Cultural Geographies 21 (1): 115-29.

Mignolo D. 2007. "DELINKING The Rhetoric of Modernity the Logic of Coloniality and the Grammar of de-Coloniality in Special Issue: Globalization and the DeColonial Option." Cultural Studies 21 (2/3): 449-514.

Mills, A.C. 2010. "Understanding the Conundrum of Rebirth Experience of the Beaver, Gitxsan, and Witsuwit'en." Anthropology and Humanism 35 (2): 172-91. doi:10.1111/j.1548-1409.2010.01065.x.

Mills, A.C., 1994. Eagle down is our law: Witsuwit'en law, feasts, and land claims. UBC Press.

Morden, M. 2015. "Right and Resistance: Norms, Interests and Indigenous Direct Action in Canada." Ethnopolitics 14 (3): 256-76. doi:10.1080/17449057.2014.949444.

Muldoon, P. 2008. "The Sovereign Exceptions: Colonization and the Foundation of Society." Social \& Legal Studies 17 (1): 59-74. doi:10.1177/0964663907086456.

Muldoon, P. 2005. "Thinking Responsibility Differently: Reconciliation and the Tragedy of Colonisation." Journal of Intercultural Studies 26 (3): 237-54. doi:10.1080/07256860500153518.

Napoleon, V. 2005. "Delgamuukw : A Legal Straightjacket for Oral Histories?" Canadian Journal of Law and Society 20 (2): 123-55. doi:10.1353/j1s.2006.0025.

—. 2013. "Thinking About Indigenous Legal Orders." In Dialogues on Human Rights and Legal Pluralism, edited by René Provost and Colleen Sheppard, 22945. Ius Gentium: Comparative Perspectives on Law and Justice 17. Springer Netherlands. http://link.springer.com/chapter/10.1007/978-94-007-4710-4_11.

Neimanis, A., Castleden, H. and Rainham, D. 2012. "Examining the Place of Ecological Integrity in Environmental Justice: A Systematic Review.” Local Environment 17 
(3): 349-67. doi:10.1080/13549839.2012.665863.

Newell, P. 2005. "Race, Class and the Global Politics of Environmental Inequality." Global Environmental Politics 5 (3): 70-94.

Neville, K.J. and Weinthal, E., 2016. Scaling up site disputes: strategies to redefine 'local' in the fight against fracking. Environmental Politics, 25(4), pp.569-592.

Nussbaum, M.C. 1997. "Capabilities and Human Rights." Fordham L. Rev. 66: 273.

O'Neill, J. 2006. Who speaks for nature? in J. Haila and C. Dyke (eds), How Nature Speaks: The Dynamics of the Human Ecological Condition. Durham NC: Duke University Press, pp. 261-78.

Overstall, R. 2004. "Encountering the Spirit in the Land: 'Property' in a Kinship-based Legal Order" in John McLaren, ed., Despotic Dominion: Property Rights in British Settler Societies. Vancouver: UBC Press.

Pasternak, S. 2014. "Jurisdiction and Settler Colonialism: Where Do Laws Meet?" Canadian Journal of Law and Society 29 (2): 145-61.

Pellow, D. N. 2009. “'We Didn't Get the First 500 Years Right, So Let's Work on the Next 500 Years': A Call for Transformative Analysis and Action." Environmental Justice 2 (1): 3-6. doi:10.1089/env.2008.0549.

Pimentel, D., Westra, L. and Noss, R.F. eds. 2000. Ecological Integrity: Integrating Environment, Conservation, and Health. 2nd edition. Washington, D.C: Island Press.

Plumwood, V. 2004. Gender, eco-feminism and the environment.Controversies in environmental sociology, 43.

Porto, M. F., and Pacheco, T. 2009. "Conflitos E Injustiça Ambiental Em Saúde No Brasil.” Tempus Actas de Saúde Coletiva 3 (4): 26-37.

Ranco, D.J., O’Neill, C.A., Donatuto J. andHarper B.L. 2011. Environmental Justice, American Indians and the Cultural Dilemma: Developing Environmental Management for Tribal Health and Well-being. Environ. Justice, 4:221-230.

Rodríguez, I. and Inturias, M.L., 2018. Conflict transformation in indigenous peoples' territories: doing environmental justice with a 'decolonial turn'. Development Studies Research, 5(1), pp.90-105.

Schlosberg, D. 2007. Defining Environmental Justice: Theories, Movements and Nature. 
Oxford New York: Oxford University Press.

Schlosberg, D., and D. Carruthers. 2010. "Indigenous Struggles, Environmental Justice, and Community Capabilities." Global Environmental Politics 10 (4): 12-35. doi:10.1162/GLEP_a_00029.

Schlosberg, D. 2013. “Theorising Environmental Justice: The Expanding Sphere of a Discourse." Environmental Politics 22 (1): 37-55.

Schlosberg. 2004. "Reconceiving Environmental Justice: Global Movements and Political Theories." Environmental Politics 13 (3): 517-40.

Scott, D. N. 2013. "The Networked Infrastructure of Fossil Capitalism: Implications of the New Pipeline Debates for Environmental Justice in Canada." Revue Générale de Droit. http://papers.ssrn.com/sol3/papers.cfm?abstract_id=2271320.

Simpson, A., 2014. Mohawk interruptus: Political life across the borders of settler states. Duke University Press.

Simpson, L., 2011. Dancing on our turtle's back: Stories of Nishnaabeg re-creation, resurgence and a new emergence. Arbeiter Ring Pub.

Sikor, T., and Newell, P. 2014. “Globalizing Environmental Justice?” Geoforum 54 (July): 151-57. doi:10.1016/j.geoforum.2014.04.009.

"Statement by Laura Holland, Wet'suwet'en Nation at the Vancouver Rally in Support of the Unist'ot'en | Vancouver Media Co-Op.” 2015. Accessed June 6. http://vancouver.mediacoop.ca/story/statement-laura-holland-wetuweten-nationvancouver/14735.

Smith, A. 2011. Against the Law: Indigenous Feminism and the Nation-State. In Glen Coulthard, Jacqueline Lasky, Adam Lewis, and Vanessa Watts (Eds.). Affinities: A Journal of Radical Theory, Culture, and Action 5(1). Special Issue on Anarch@Indigenism, 56-69.

Smith, L.T., 2013. Decolonizing methodologies: Research and indigenous peoples. Zed Books Ltd.

Tallbear, K. 2011 "Why Interspecies Thinking Needs Indigenous Standpoints." Theorizing the Contemporary, Cultural Anthropology website. https://culanth.org/fieldsights/260-why-interspecies-thinking-needs-indigenousstandpoints. 
Temper, L. 2017. 'Globalizing environmental justice Radical and transformative movements past and present', in Handbook of Environmental Justice, Ryan Holifield, Jay Chakraborty and Gordon Walker. Routledge. In Press.

Temper, L., del Bene, D. and Martinez-Alier, J., 2015. Mapping the frontiers and front lines of global environmental justice: the EJAtlas. Journal of Political Ecology, 22, pp.255-278.

Thom, B. 2014. Reframing Indigenous Territories: Private Property, Human Rights and Overlapping Claims. American Indian Culture and Research Journal: 2014, Vol. 38, No. 4, pp. 3-28.

Tuck, E. and Yang, K.W., 2012. Decolonization is not a metaphor. Decolonization: Indigeneity, education \& society, l(1).

Turner, D.A., 2006. This is not a peace pipe: Towards a critical indigenous philosophy. University of Toronto Press.

Unist'ot'en ND. https://unistotencamp.wordpress.com/free-prior-and-informed-consentprotocol/

Urkidi, L., and Walter, M. 2011. "Dimensions of Environmental Justice in Anti-Gold Mining Movements in Latin America." Geoforum 42 (6): 683-95. doi:10.1016/j.geoforum.2011.06.003.

Valladares, C. and Boelens, R., 2017. Extractivism and the rights of nature: governmentality, 'convenient communities' and epistemic pacts in Ecuador. Environmental Politics, pp.1-20.

Vermeylen, S. 2013. 'The Nagoya Protocol and Customary Law: The Paradox of Narratives in the Law', Law, Environment and Development Journal. 9/3.

Vermeylen, S. and Walker, G., 2011. Environmental justice, values, and biological diversity: The San and the Hoddia benefit-sharing agreement. Environmental inequalities beyond borders: local perspectives on global injustices. MIT Press, Cambridge, Mass, pp.105-128.

Wa, G., and Delgam. U. 1992. The Spirit in the Land: Statements of the Gitksan and Wet'suwet'en Hereditary Chiefs in the Supreme Court of British Columbia, 19871990. Reflections.

Warner, E.A.K., 2015. Working to Protect the Seventh Generation: Indigenous Peoples 
as Agents of Change. Santa Clara J. Int'l L., 13, p.273.

Westra, L. 2012. Environmental Justice and the Rights of Indigenous Peoples: International and Domestic Legal Perspectives. Earthscan.

Whyte, K.P. 2016. "Indigenous Experience, Environmental Justice and Settler Colonialism.” SSRN Scholarly Paper ID 2770058. Rochester, NY: Social Science Research Network. http://papers.ssrn.com/abstract=2770058.

Whyte, K.P., 2011. The recognition dimensions of environmental justice in Indian Country. Environmental justice, 4(4), pp.199-205.

Wilkes, R, Corrigall-Brown, C. and Myers, D.J. 2010. "Packaging Protest: Media Coverage of Indigenous People's Collective Action." Canadian Review of Sociology/Revue Canadienne de Sociologie 47 (4): 327-57.

Young, I.M., 2011. Justice and the Politics of Difference. Princeton University Press.

Young, I.M., 2000. Hybrid democracy: Iroquois federalism and the postcolonial project. Political theory and the rights of indigenous peoples, pp.237-58 